Pontifícia Universidade Católica

do Rio de Janeiro

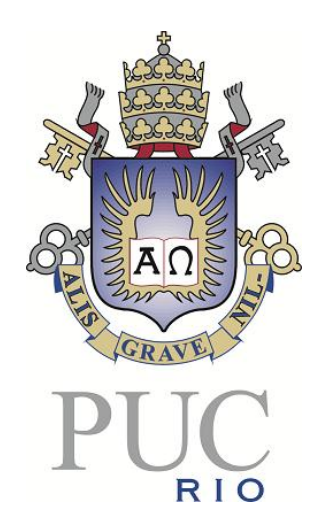

Hugo Taam Dart

\title{
An investigative look at two World War I poems
}

Monografia apresentada como requisito parcial para obtenção do grau de Especialista em Língua Inglesa pelo CCE da PUC-Rio.

Prof $^{\text {a. }}$ Adriana Nogueira Accioly Nóbrega Orientadora Departamento de Letras - PUC-Rio 
Here dead we lie, Because we did not choose to live And shame the land from which we sprung.

Life, to be sure, is nothing much to lose, But young men think it is, And we were young.

A E Housman 


\begin{abstract}
This monograph aims at understanding the ways World War I English poets Rupert Brooke and Wilfred Owen create their desired semantic effects in the poems The Soldier and Dulce Et Decorum Est, respectively. The analysis was carried out with the use of concepts from the Appraisal system (MARTIN, 2000b). Additionally, two Exploratory Practice activities were conducted, and provided complementary perspectives on the manner in which the poems are read by contemporary audiences, as a fellow English teacher and a group of advanced English students shared their own views on the two pieces. A number of results were reached, and the manners in which Brooke and Owen produced two of the most representative pieces of war poetry became clearer, as did the manners in which those poems reach today's readers.
\end{abstract}

Key words: Rupert Brooke, Wilfred Owen, war poetry, appraisal, systemic functional linguistics, semantic effect. 


\section{Contents}

1. Introduction _ 5

2. Theoretical Background___ 6

3. Methods 10

3.1. The Exploratory Practice Activities___ 11

3.2. The Poems___ 13

4. Analyses of the Poems ___ 16

4.1. The Soldier___ 16

4.2. Dulce Et Decorum Est ___ 24

5. Analysis of the Exploratory Practice Activities___ 35

5.1. First Activity___ 35

5.2. Second Activity __ 37

6. Conclusions__ 40

7. References __ 42 


\section{Introduction}

Among the numerous readers of poetry, there are those like myself, who believe to be able to tell when a certain poem speaks to them, and when it does not. Besides whatever feelings and idiosyncrasies may be at play at any given situation, the skill of the author in the use of linguistic features has an importance that may not be immediately apparent to some of us. Studying different aspects of language, such as the ones investigated by Michael Halliday and James Martin, could help those readers enhance their understanding of the ways in which intended meaning are construed.

My own interest in Rupert Brooke's The Soldier and Wilfred Owen's Dulce Et Decorum Est has come a long way. It was born in early May, 2014, at the $14^{\text {th }}$ Braz-Tesol International Conference, when a presenter slightly misquoted the first verses of a poem which I did not know, and would later find out was called The Soldier. The presenter had gotten close enough to the actual verses to leave an impression. A few months later, when I was just starting this post-graduation course, the first group activity in Language Studies I required each of the four members of each group to produce an analysis of a text in a different genre. I chose The Soldier. As I prepared for the group presentation, I came across a number of texts that mentioned that that poem was often contrasted to Dulce Et Decorum Est, which I felt to be at least as intriguing as the other one. By the end of that initial semester, I already knew that I wanted this monograph to be about the two poems, and approached Professor Adriana Nóbrega, whom I hoped would agree to be my advisor, on the very last day before our summer vacation.

From the moment I started studying them, I found The Soldier and Dulce Et Decorum Est to be highly representative examples of two opposing attitudes towards the sacrifice made by World War I soldiers - a sacrifice that the authors themselves would make, as poet soldiers who died during the War, not very long after writing those poems. Brooke wrote at the beginning of the War, having been to it but unaware, as most people were at the time, of the true horrors that were about to arise. His Soldier is the ultimate celebration of how wonderful it is to die for one's country. In stark contrast, Owen, who enlisted after Brooke's 
death, experienced such horrors firsthand and eventually set as a declared goal to alert the people about the unmitigated tragedy of war, which he does in his poem.

This monograph aims at understanding what semantic effects are created by means of the choices made by Brooke and Owen, and at investigating how the poems reach today's readers - namely, an English teacher and a group of advanced English students. Through a Systemic Functional Linguistic (SFL) perspective - as developed by Michael Halliday (HALLIDAY; HASAN, 1989; EGGINS, 2004) - and resorting in particular to Appraisal analysis as explained in the work of James Martin (MARTIN; WHITE, 2005), each verse in the poems is examined. In addition, the results of a couple of Exploratory Practice (EP) activities (ALLWRIGHT, 2001) which were motivated by the very classes of this post-graduation course reveal ways in which the two poems are read by a teacher and a few students who were exposed to the texts.

\section{Theoretical Background}

It may be difficult for people who were born decades after the end of the conflict to imagine what an important role poetry played in World War I Britain. According to David Roberts $(1996$, p.15), the short poetry of that time could be compared to television news bulletins that reported on later wars, in terms of the urgency with which poets let their countrymen know of the horrifying scenes that played out in the battlefield. Besides that, some of the best of those authors were also responding to lesser peers. That was the case of Wilfred Owen himself, in the poem that is analyzed herein (ibid.).

If Owen's qualities as a poet - including his unique ability to translate his experiences as a soldier into verse - have some authors place him among England's greatest, Rupert Brooke's powerful rhetoric, while a reflection of his talent, hides a man who lacked some clarity in his ideas (ibid., p. 16). Going to war earlier than the other poet soldiers, Brooke responded to the threat of death by artillery fire with sentiments that evoked "thrill and 
patriotic duty to a mythical land that must have seemed remote, if beautiful, to most soldiers" (EGREMONT, 2014, p.46). The impact of his words endures to this day.

The connection between the two poets can be traced with little difficulty. In November of 1915, just after enlisting, Owen bought a copy of a posthumously published edition of Brooke's poems (ibid., p. 67). His enthusiasm for fighting for England would develop slowly, though, and the feeling that it was necessary to provide a counterpoint to pro-war poets would come even later, after he himself suffered from 'shell-shock', which we now call post-traumatic stress disorder.

The poems by Rupert Brooke and Wilfred Owen that are analyzed herein form a unique pair for a number of reasons. From a genre perspective, they are both World War I poems, written by Englishmen who were also combatants during the war. That shows us that they come from the same cultural background, as their authors shared some fundamentally identity-defining circumstances.

There is little room for controversy in this regard. The Soldier and Dulce Et Decorum Est were written and have always been read as war poems. So representative of the genre are they that excerpts from each have been used as titles of books about World War I poetry - A Corner of a Foreign Field (Croxley Green: Atlantic Publishing, 2007) from the former and Some Desperate Glory (EGREMONT, 2014) from the latter (Fig. 1).
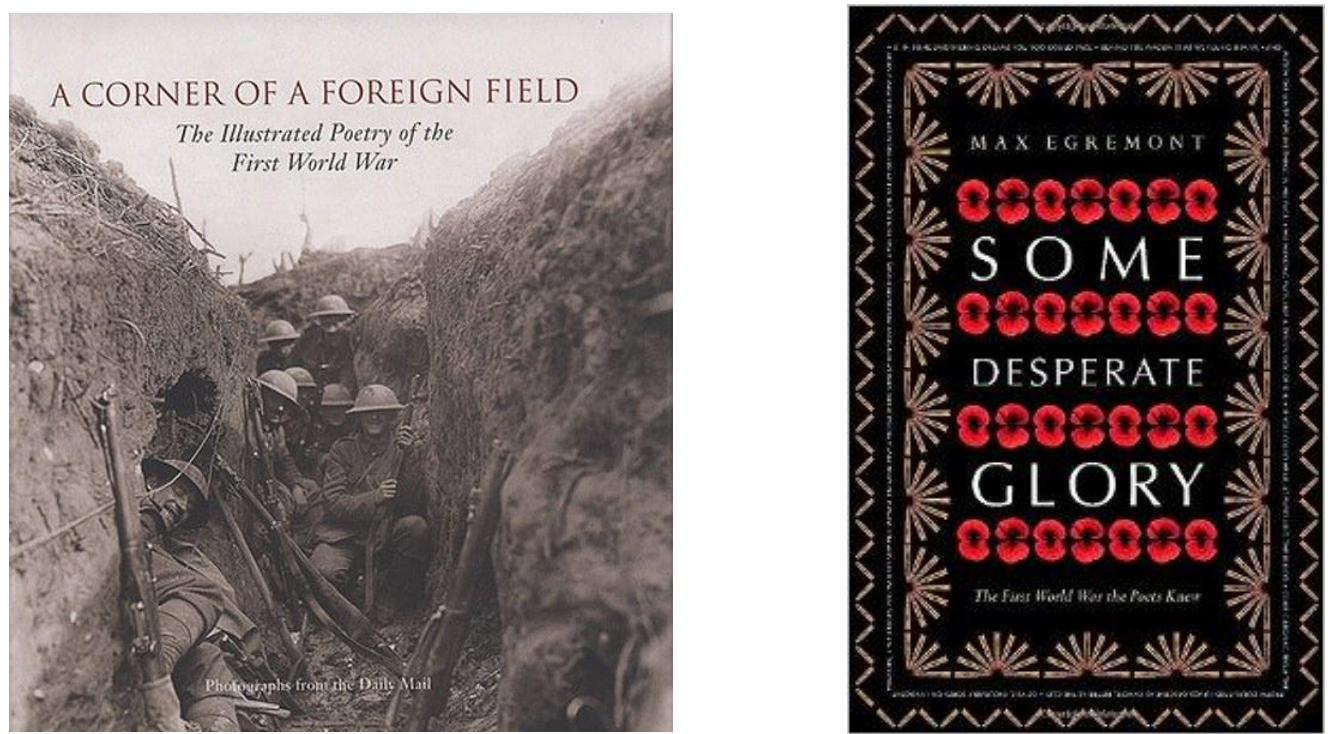

Figure 1: Examples of books with titles taken from the two poems 
In terms of structure, Brooke's poem is in a Petrarchan sonnet form, with an opening octet and a closing sestet, written in iambic pentameter. Owen's is in two parts, with an 8line and a 6-line stanza in the first and a 2-line and a 12-line stanza in the second.

From a theoretical standpoint, this research drew on analytical tools from the Appraisal System developed by a group led by Professor James Martin, from the University of Sydney. The Appraisal System was formulated within the Systemic Functional Linguistic (SFL) paradigm designed by Michael Halliday and his collaborators. According to Halliday, "a text is essentially a semantic unit", an "instance of living language that is playing some part in a context of situation" (HALLIDAY; HASAN, 1989, p. 10). That context of situation comprises extralinguistic features of a text which make it what it is. It is always inserted in a context of culture, which can be described as "the sum of all the meanings it is possible to mean in that particular culture" (BUTT et al, 2000, pp. 11-12), and is responsible for the schematic or rhetorical structure of a text.

In this view, the use of language has the function of making meanings. Those meanings are connected with the contexts in which exchanges take place, and in which choices are made in the production of every utterance (EGGINS, 2004, p. 3). In the words of Suzanne Eggins, understanding language as a social semiotic system makes it possible for us to focus on how each choice results in language that makes meanings and is appropriate or inappropriate in relation to its context (ibid.). That is an expression of the interdependent and dialectical relation that exists between text and context.

Three features of context are particularly relevant to language use. They are the register variables identified as "mode (amount of feedback and role of language), tenor (role relations of power and solidarity) and field (topic or focus of the activity)" (ibid., p. 9). Halliday also identifies three metafunctions, which correspond to the three main purposes for which language seems to have evolved and which relate to the register variables: Ideational (related to field) - to talk about what is happening, what has happened, what will happen - Interpersonal (related to tenor) - to interact and/or to express a point of view and Textual (related to mode) - to organize the two previous meanings into a coherent whole (BUTT et al, 2000, pp. 13-14). 
Martin focuses on the interpersonal metafunction of language and on how those who produce texts "approve and disapprove, enthuse and abhor, applaud and criticize, and with how they position their readers/listeners to do likewise" (MARTIN; WHITE, 2005, p. 1). Appraisal is made up of three domains which interact with each other - Attitude ("our feelings, including emotional reaction, judgments of behavior and evaluation of things"), Engagement ("sourcing attitudes and the play of voices around opinions in discourse") and Graduation ("grading phenomena whereby feelings are amplified and categories blurred") (ibid., p. 35).

The domain of Attitude, by its turn, is divided in the three regions of feeling with which this analysis concerns itself: Affect, Judgment and Appreciation. Affect has to do with how one feels; judgment, with attitudes according to which behavior is either admired or criticized, praised or condemned; appreciation, with evaluating semiotic and natural phenomena, which in any given field may be valued or not (ibid., pp. 42-43). Linguistic choices made by the author of a given text may convey affect, judgment or appreciation which is either positive or negative, and which is stronger or - often by means of modalization - weaker.

Exploratory Practice is presented by Dick Allwright as a teacher development strategy that consists in action for understanding (ALLWRIGHT, 2001). Therefore, it differs from Reflective Practice because it involves action, and from Action Research because it does not aim at making changes. The researcher simply collects or generates data which are to further their understanding of the chosen topic. Allwright is very clear on how EP is about developing situational understanding rather than producing practical solutions to practical problems (ALLWRIGHT, 2000).

After the identification of what it is that puzzles the researcher, there is occasion for reflecting on the issue. When necessary, that step may be followed by monitoring, and if that is still not enough to reach the desired understanding, the adaptation and/or creation of potentially exploitable pedagogic activities (PEPAs). Allwright emphasizes the point that standard pedagogic activities rather than standard academic data-collecting techniques should be used at that stage (ibid.). 


\section{Methods}

As the objective of this research is to understand the linguistic features that are present in Rupert Brooke's Wilfred Owen's poems so that the semantic effects intended by the authors are realized, the data with which I worked were only the two poems themselves. The method was to analyze them verse by verse, guided by Appraisal notions from Systemic Functional Linguistics.

Because my intention was to identify the linguistic choices - as in verbs, adjectives and so on - that were made by Brooke and Owen in such a way that The Soldier and Dulce Et Decorum Est became powerful representatives of opposing points of view towards the idea of dying for one's country, it was necessary to look at every part of speech and its meaning, and its intended effect on readers. Identifying what instances of affect, judgment and appreciation are present in the poems led to an increased understanding of the texts, for those choices can make us aware of the authors' positioning towards the experiences they narrate or upon which they reflect.

As the purpose of this research is to investigate aspects of and already established amount of data rather than to measure it, it is characterized as qualitative rather than quantitative. Among the various paradigms described by authors such as Yvonna Lincoln and Egon Guba, it is the constructivist one which seems to apply. The reason is that, in contrast with what is intended in other paradigms, I aim at describing something of which I am not a part, and intend to change nothing, but only to describe what I observe. The constructions are "local and specific in nature (although elements are often shared among many individuals and even across cultures)" (GUBA; LINCOLN, 1994, p. 110). As I identify instances of affect, judgment and appreciation within the poems, the interaction between the object of the investigation and the investigator creates the findings, as do the two EP activities themselves, when the participant teacher and students reflect upon the texts and exteriorize their own views. It is a key issue that the realities that are produced in this investigation which are the findings of this research - are the product of the intellect of the abovementioned participants and that, as each of us becomes "more informed and 
sophisticated", such realities may change (ibid., p. 111). Rather than a shortcoming, this aspect of the paradigm is connected with the importance of dialogue and negotiations on which the validity of constructs depends (GUBA; LINCOLN, 2000, pp. 177-178).

\subsection{The Exploratory Practice Activities}

During the Exploratory Practice module of this post-graduation course, all students were asked to consider their respective projects from that perspective. Although I initially had some trouble seeing how I could possibly apply EP to such a self-involved endeavor as this, two ideas came from my conversations with Professors Inés Kayon de Miller and Maria Isabel Cunha. Fortunately, I had the opportunity to put them into practice, and could see how much they added to my own understanding of the two poems. My participation in the Poster Session that brought an end to our classes, on December $10^{\text {th }}, 2015$, consisted in a presentation about the two activities.

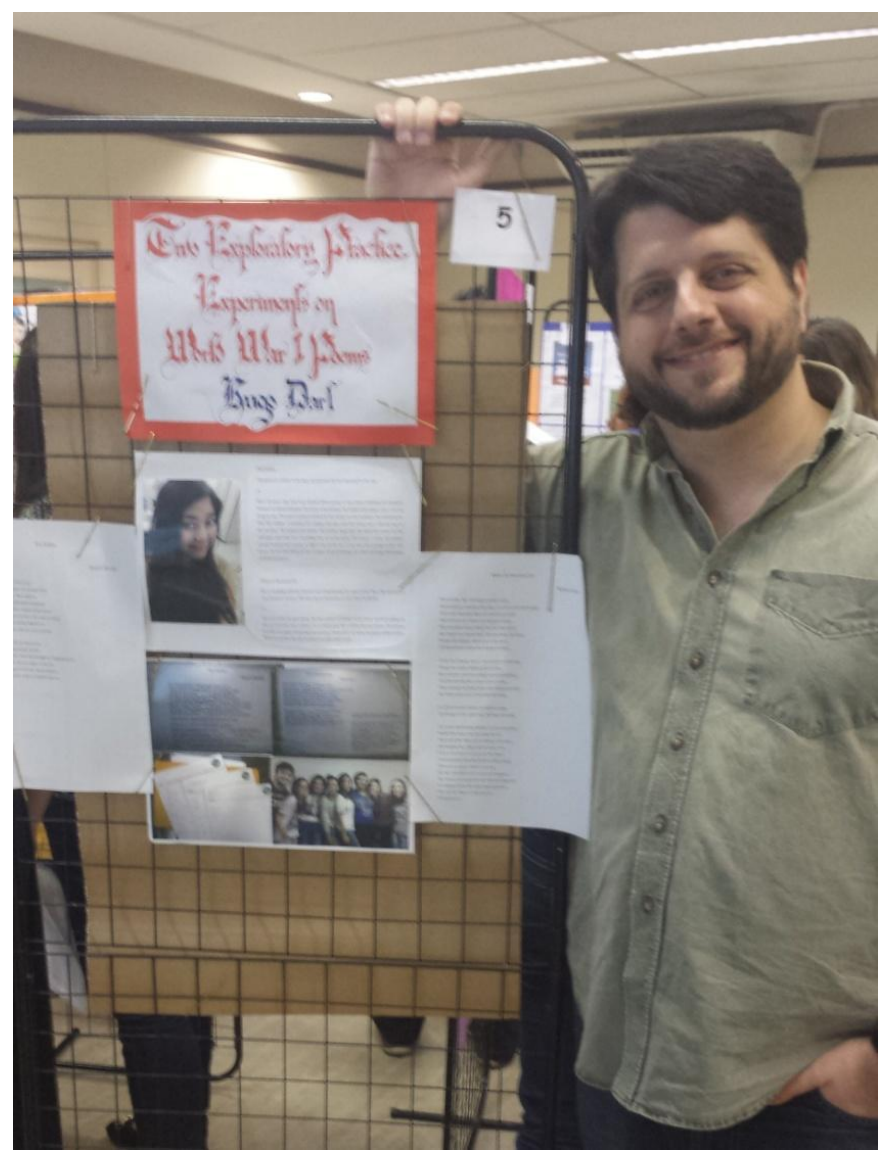

Figure 2: My Poster 
The first idea came up in the second of the six classes. As homework for the third class, we were supposed to do some sort of monitoring, which is "a matter of somehow paying special attention to the phenomenon" that puzzles the researcher (ALLWRIGHT, 2000). I did not seem to have any classroom event to observe that was relevant to this research, but I could try and get another reader's thoughts on the poems. On September $20^{\text {th }}, 2015$, I read both to English teacher Sandra Saito, who works with me, and asked her to share freely what impressions came to mind. I recorded her comments with my cell phone and transcribed in Section 5.1 the most relevant passages.

The idea for the second activity came up in our fourth class, when we were told about the posters that were to be produced for our final event of the course, on December $10^{\text {th }}$. As I looked at posters from previous years, I decided to do a cloze activity with some of my teenage advanced students at the private language course in which I work. That seemed to be appropriate because EP can be carried out in the classroom by using normal pedagogic practices as investigative tools (ibid.). On October $26^{\text {th }}, 2015$, I presented students with the two poems, a few words removed from each one. I explained to the students from where the poems were, and that I was challenging them to come up with possible ways to fill in the gaps. So that they would not be influenced by my own views or expectations, I said nothing about this research at the time. Because there were only eight students present and because I wanted them to have a chance to exchange ideas before getting to their final answers, the class was divided in three groups of two or three participants each, whose contributions are reproduced in Section 5.2 .

For the purposes of this research, a decision was made to develop the analysis of the linguistic choices and the contexts in which they took place more than the Exploratory Practice activities, but it is clear that further development of the EP section would generate useful data. Therefore, a next step for this study would be to expand that section by including interviews with more than one teacher and the participation of other groups of students. In both activities, contributors would be asked to elaborate upon their choices. That would lead to a more detailed picture of how the poems arrive at the contexts of culture and of situation in which we are inserted. 


\subsection{The Poems}

The Soldier

Rupert Brooke

If I should die, think only this of me:

That there's some corner of a foreign field

That is for ever England. There shall be

In that rich earth a richer dust concealed;

A dust whom England bore, shaped, made aware,

Gave, once, her flowers to love, her ways to roam;

A body of England's, breathing English air,

Washed by the rivers, blest by suns of home.

And think, this heart, all evil shed away,

A pulse in the eternal mind, no less

Gives somewhere back the thoughts by England given;

Her sights and sounds; dreams happy as her day;

And laughter, learnt of friends; and gentleness,

In hearts at peace, under an English heaven.

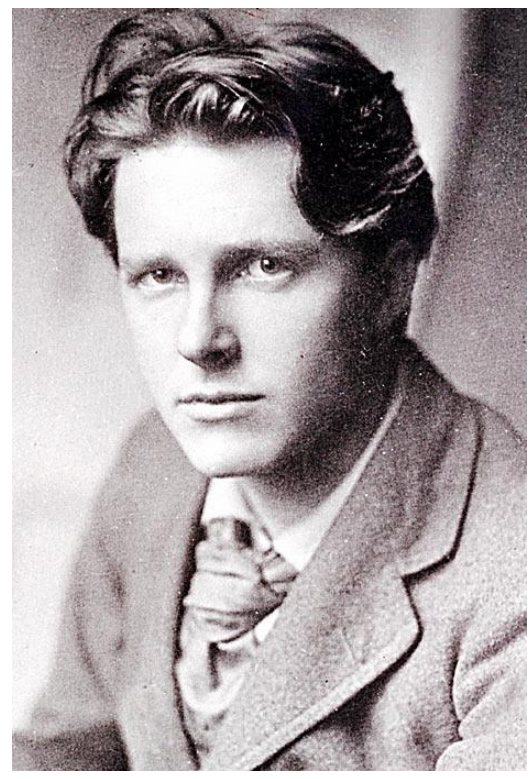

Figure 3: Rupert Brooke 


\section{Dulce Et Decorum Est}

Wilfred Owen

Bent double, like old beggars under sacks,

Knock-kneed, coughing like hags, we cursed through sludge,

Till on the haunting flares we turned our backs

And towards our distant rest began to trudge.

Men marched asleep. Many had lost their boots

But limped on, blood-shod. All went lame; all blind;

Drunk with fatigue; deaf even to the hoots

Of disappointed shells that dropped behind.

GAS! Gas! Quick, boys!-- An ecstasy of fumbling,

Fitting the clumsy helmets just in time;

But someone still was yelling out and stumbling

And floundering like a man in fire or lime.--

Dim, through the misty panes and thick green light

As under a green sea, I saw him drowning.

In all my dreams, before my helpless sight,

He plunges at me, guttering, choking, drowning.

If in some smothering dreams you too could pace

Behind the wagon that we flung him in,

And watch the white eyes writhing in his face,

His hanging face, like a devil's sick of sin;

If you could hear, at every jolt, the blood

Come gargling from the froth-corrupted lungs,

Obscene as cancer, bitter as the cud

Of vile, incurable sores on innocent tongues,-- 
My friend, you would not tell with such high zest

To children ardent for some desperate glory,

The old Lie: Dulce et decorum est

Pro patria mori.

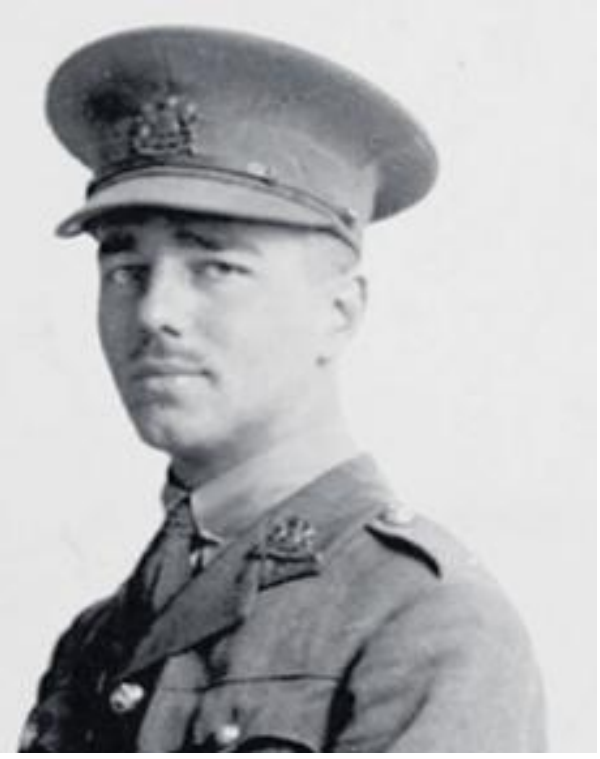

Figure 4: Wilfred Owen 


\section{Analyses of the Poems}

What follows is my analysis of the two poems in the light of Systemic Functional Linguistics and the Appraisal System.

\subsection{The Soldier}

\section{If I should die, think only this of me:}

Brooke begins with the modalization expressed by should, by which the hypothesis of the narrator's death seems to be deemed more remote than if he had said If I die. The death of a soldier that goes to war is always a possible outcome, but Brooke does not wish his reader to see it as an impending inevitability.

The imperative think in the second clause establishes the dialogic relationship between poet and reader as monoglossic, as the absence of a modal formulation such as you should think or you must think does not allow for an alternative possibility. It is a direct command, one which is immediately reinforced by the word only. Whatever follows the colon - and nothing else - is what the reader is to think of the narrator. The reader, by their turn, understands from the use of the imperative and lack of modality that no other option is given to them, and that they are about to be introduced to what the narrator wants them to think of him.

\section{That there's some corner of a foreign field that is for ever England.}

The reference to the site where the soldier will be buried contains a number of indications that the place is an undetermined one. Some corner is not a specific corner, but a random one. The choice of the noun corner is itself significant, as a corner is an unremarkable place, probably undistinguishable from the area that surrounds it.

What we also learn about the grave here is that it is not in England, but in a foreign field. The narrator apparently expects his death to occur overseas, as he is to be sent to fight in other 
countries. However, he does not seem to know, or wish to reveal, which one it is. A foreign field can be in any country where the war is being fought.

Brooke establishes the central image of his poem in saying that the narrator's grave, although located abroad, is for ever England. His body, and later his corpse, is a piece of his homeland, as in the international diplomatic convention according to which a country's embassy is considered part of its territory, rather than part of the territory of the country that hosts it. Here, however, there is no legal agreement between nations. Brooke is the one that affirms that the soldier's dead body is part of England, and forever so. That notion is at the core of what the poet instructs his readers to think of him.

Brooke seems to be construing the strong sense of patriotism that is required from soldiers and citizens who love their country. The narrator is gradually revealed to be a soldier who is not only patriotic enough to die for his country, but one whose death may even be welcome, if it happens in the name of the country.

\section{There shall be in that rich earth a richer dust concealed;}

That is what shall happen, and in that modality the author still distances himself from the future he predicts. What he describes is what he expects will happen, not something about which he is sure. For the reader, it is therefore a possibility, rather than a certainty, that there is to be richer dust in that rich earth.

Dead, the soldier becomes dust - "ashes to ashes, dust to dust" -, and is going to be buried in soil that is rich, fertile. His corpse, however, is even richer, because it is part of England. As the bodies of Union soldiers who died during the Battle of Gettysburg, in the American Civil War, had consecrated the soil in which they were buried far above Lincoln himself could (ABRAHAM LINCOLN ONLINE), so does the body of the English soldier make that rich earth even richer.

The use of the comparative form richer can be interpreted as establishing a continuum in which the soil of the land where the narrator's body is buried is at an inferior degree than the organic material that is the corpse itself. In this case, the continuum might be one of moral worthiness or, in a more literal sense, of fertility, which would reinforce the notion that dying for England is worth it. Turned back into that richer dust, the corpse would symbolize 
not the end of a portion of the country, but its continuation - and even its expansion to that foreign land.

The notion of appraisal is at play here, as the positive value of the adjective rich and the intensification expressed by the use of the comparative form seem to tell the reader what is the point of view of the author about the land and about the dead body.

Finally, here, it should be clarified that concealing does not seem to be associated with the intention of deceiving. The richer dust is concealed simply because it is underground, representing England.

\section{A dust whom England bore, shaped, made aware,}

The three verbs seem to illustrate, in chronological order, the very beginning of the narrator's existence. There appears to be another continuum here, in which the successive steps of formation of the narrator are in a crescendo - the person is first born, then acquires the individualized shape of a recognizable human being that is distinct from all others, and then becomes self-aware and aware of what there is in the world that surrounds him.

The country itself is the agent. It was England, rather than his parents or any other entity, which gave birth to him, shaped him and gave him consciousness.

\section{Gave, once, her flowers to love, her ways to roam;}

The use of the feminine pronoun to refer to the country is a marker of animacy which is in consonance with the author's intention to present England as a benign entity, one whose generosity appears to be expressed by the verb give. The feminine entity would be the motherland, the mother who gives life itself and who teaches all that is essential.

Once could indicate an indeterminate time in the narrator's life, when he was younger and could enjoy England's flora and paths. As the reader is presented with the information that English flowers were to be loved and English ways to be roamed, appraisal analysis indicates how the positive character of the country's features is highlighted. Both that flora and those paths are some of the nice, pleasant features of a beautiful nation. 


\section{A body of England's,}

The phrase that indicates that the narrator's body belongs to England seems to reinforce the initial idea that his body will one day be a part of his homeland abroad. The ownership that is expressed in the verse tells the reader once again that the soldier and his country cannot be separated.

\section{breathing English air,}

\section{Washed by the rivers, blest by suns of home.}

Those three phrases may be seen as forming another continuum, one in which there is a progression of positive effects that certain features of England have had on the narrator. Firstly, there is the air that has been breathed by him. The action of breathing might not be seen as positive or negative itself, but the fact that it is English air appears to tell the reader that that air is special - positively appraised because it is from England. Then, there are the rivers, also special for being English, that have washed him, in an action containing a positive value associated with the cleansing of what is impure. Finally, the suns of home have blest the narrator, which is a lot more than simply warming him. In the continuum, blessing can be seen as holding the highest position. The reader is thus informed, again in a crescendo, of the positive impact of England on the narrator.

The plural in suns is not likely to be literal, but rather a reference to each new day that has been lived by the narrator while in England. However, another possible interpretation is that the verse also contains the same pun that is in the opening lines of William Shakespeare's Richard III - "Now is the winter of our discontent/Made glorious summer by this sun of York" - in which the title character is referring both to the sun in the sky and to his brother, the king, son of the York house. As the poem is read, the homophony could cause the reader to think also of the sons of England - the narrator's countrymen, his friends and relatives, who have also blest him. 


\section{And think,}

The second stanza begins with the same imperative that is at the beginning of the poem. The instructions given by the author to the reader continue, and the repetition of the command verb seems to reinforce that. Again, it should become clear to the reader that they are still expected to think about the narrator that which they are told.

this heart, all evil shed away,

At that time when the narrator is dead, all evil leaves his heart. The author's use of the past participle form of shed appears to be a case of nominalization. By writing "all evil shed away" instead of "when all evil is shed away" or "when all evil has been shed away", he seems to leave no choice for readers but to accept that all evil has indeed been shed away, which is a premise for what follows in the next verses.

That premise is an important one, for it establishes the author's heart as having been purified. Even more than that, as the narrator might be using heart not in a literal sense but as a metaphor for his own identity, he could be characterizing himself, now a dead body, as purified.

\section{A pulse in the eternal mind, no less}

This next verse seems to build on the idea that the narrator has been purified and take it to the next level, as the heart - or the narrator himself - is now no less than a pulse in the eternal mind, which is a very strong image, and perhaps the highest possible form of purity. A pulse is not something material, but motion itself - an expression of energy. The eternal mind, by its turn, could be a supernatural entity, akin to a deity or to the universe itself, in a romanticized, personified notion, as mind is associated with intelligence.

Instead of saying that "that heart will be a pulse in the eternal mind", Brooke leaves the verb out. Once again, the fact that there is no verb indicates the occurrence of nominalization, and the reader appears to be left with no choice but to accept that the narrator will indeed 
become a pulse in the eternal mind when he dies. The nominalization leaves no room for negotiation.

\section{Gives somewhere back the thoughts by England given;}

It is only here that the second verb of the second stanza of the poem comes, after the imperative think of the first verse. This is what the purified heart, now having reached the stage of pulse, does: it gives something back to England. That takes place somewhere, which is an unidentified site. Just as the precise location of the "foreign field" of the second verse of the poem is never revealed, the author again seems not to wish to tell the reader where exactly he expects the soldier to die and be buried. The foreign field, after all, could conceivably be in any one of the several countries where the War was taking place.

What follows the verb is a list of everything that the soldier will give back. The list begins in the same line, with "the thoughts by England given". Although the use of the phrasal verb gives back already seems to indicate the narrator will return something after he dies, it is with "by England given" that the reader is told that the country is the one that gave, and will now receive, what the narrator will return. The thoughts, and what follows in the next verses, are something that England gave him first at some point, rather than something that originated within the soldier himself or that was given to him by anyone else.

\section{Her sights and sounds; dreams happy as her day;}

The list of what the narrator will give back to England after he dies seems to continue in this verse. It is the sights of England, the sounds of England - both of which the soldier would have experienced when during his life there - and dreams. Those dreams are characterized as possessing as much happiness as the days spent in the country. This could indicate the positive appraisal of the life lived by the narrator in England, including both the hours he spent awake and the hours he spent asleep, dreaming. 


\section{And laughter, learnt of friends; and gentleness,}

The list of positively appraised items seems to continue in this verse, first with laughter, which indicates joy, fun and, again, happiness. That laughter was "learnt of friends", which seems to place the narrator's youth in the company people who had a positive impact on him. If the narrator says that they 'taught him to laugh', that could indicate to the reader that they were a source of joy in his life.

The final item in the list is gentleness, another positively appraised quality, and one which is normally associated with friendliness and caring for someone else's feelings.

In its entirety, the list could leave readers with the impression that all that England once gave to the narrator was positive, which amounts to positive appraisal of England itself. It is the country's being such a wonderful, even idyllic place that makes dying for it worth it.

\section{In hearts at peace, under an English heaven.}

The last verse seems to tell the reader that all that was given to the narrator by England was present in peaceful hearts, which could be seen as a contrast to the violence of the war the soldier went to fight. As with the narrator's heart, which might represent his own identity, here too the author may be using the word as a substitute for people - who would be the soldier's loved ones, those with the laughter and the gentleness.

The choice of "English heaven" rather than "English sky" could be reinforcing one last time the positive appraisal or the country. While sky can be understood as a more neutral word, heaven appears to bring forth once more the idea of blissful perfection and perhaps even a connection to the "eternal mind".

The semantic effect achieved by Rupert Brooke is a very powerful one. By expressing how thankful he is to England for all that the country has given him, he justifies his pride in the possibility of dying for it and then remaining forever a small piece of it abroad. The England that he describes is no ordinary country, but an idealized, mythical place for which it is worth dying. 
Highly articulate, privileged, well-educated and very sensitive, Rupert Brooke was the most famous young poet of his time. In late 1914 and early 1915, after participating in a failed effort to defend Antwerp, he wrote a series of five sonnets, which included The Soldier. They were resounding, assertive poems that glorified England and the idea of dying for England (ROBERTS, 1996).

Writing at the beginning of the war, at a time when the horrors of $20^{\text {th }}$ century warfare were still unknown and the national mood was that of admiration for military heroism, Brooke hadn't been seriously affected by his time in Belgium. His sonnets express better than virtually any other literary piece of the time the identification between man and nation, and the ultimate glory that is dying for that nation - to the point that the third sonnet in the series, The Rich Dead ("There's none of these so lonely and poor of old/But, dying, has made us rarer gifts than gold"), mirrors a speech Henry $V$ makes to his soldiers in the eponymous play by Shakespeare ("For he to-day that sheds his blood with me/Shall be my brother; be he ne'er so vile,/This day shall gentle his condition").

Brooke sailed for the Mediterranean in March of 1915, on the way to what would be the disastrous Gallipoli campaign. In Egypt, he suffered from sunstroke and a mosquito bite that turned septic. With acute blood poisoning, he died on April $23^{\text {rd }}$, when his ship was anchored off the Greek island of Skyros, and was buried there, thus fulfilling the premise of The Soldier - there is indeed "a corner of a foreign field that is forever England".

The influence of The Soldier extends into outer space. The speech drafted by William Safire for President Richard Nixon, to be used if the first moon landing did not go as planned and Neil Armstrong and Edwin Aldrin had been stranded on Earth's satellite, read that "there is some corner of another world that is forever mankind" (SAFIRE, 1999). 


\subsection{Dulce Et Decorum Est}

\section{Bent double, like old beggars under sacks,}

Throughout the entire poem, Owen uses figurative meanings in the intensification of processes. The first example is in the first verse, where the exhaustion felt by the group of soldiers has them walking bent double, and not upright as strong fighters would. There is a stark contrast with the traditional image of powerful young men in the first simile, like old beggars under sacks. The soldiers are in such a state that they look like beggars, and old ones at that - therefore even more frail -, and ones that are under heavy weights - under sacks.

In the continuum that can be seen in that image, the notion of appraisal seems to apply, as negative elements are progressively added on top of each other, thus creating for the reader an image of the soldiers as beings in a terrible condition. Those who walk are helpless like beggars; more than that, they are weak like old beggars; more than that, they are submitted to heavy loads like old beggars under sacks.

\section{Knock-kneed, coughing like hags, we cursed through sludge,}

The soldiers' legs are curved inward at the knees, which is another reason they cannot walk properly. They are also coughing like hags. In this second simile, the soldiers are compared to ugly old women. Their coughing seems to indicate they are sickened.

The subject pronoun we tells the reader that the narrator is telling his own story of suffering. He was one of the men in such a terrible state, the state of one who can barely walk, coughs from possible sickness, curses and moves along unwelcoming terrain.

The terrain is thick, wet mud, difficult to walk on. It is perhaps the very same rich earth in which Rupert Brooke's soldier is to be buried, but seen in a rather different light. Owen and his comrades have to curse through it. The expression of their negative feelings towards their condition is part of what makes them go. As Andrew Barker (MYCROFTLECTURES-b) 
points out, although 'curse' is not a verb of movement, it is made one by Owen. The reader might here imagine that the force of anger is in itself capable of driving the soldiers onwards. In the choice of the noun sludge, there is negative appraisal, for one would rather walk on firm ground than on sludge, so the reader might consider that to be one more element that indicates how undesirable the situation of the soldiers is.

\section{Till on the haunting flares we turned our backs}

The soldiers turn their backs on the bombs that are exploding. Their flares are haunting, for they keep on coming back to the men's minds. Haunting is what a ghost would do, visiting or permanently living in a certain place. The phrase 'haunting flares' can be read as the first indication of the traumatizing characteristic of war-time experiences, which is an aspect that is at the center of the author's perspective. As explained in the previous sections, Wilfred Owen spent a significant amount of time in hospital, being treated for the consequences of his own traumatizing experiences.

\section{And towards our distant rest began to trudge.}

This new description of how the soldiers move tells the reader once again how slowly and heavily they walk. The men are cursing and trudging, because they are angry and tired. The verbs chosen by Owen make it clear that, whether they have been defeated in battle or not, they feel defeated. They are walking in the direction of their resting place. Perhaps they are going back home, perhaps only to their base camp. Either way, it is far away, which means that the cursing and trudging will have to go on for some time.

Characterizing the soldiers' rest as distant could also mean that it is psychologically so. That adjective can be interpreted as an indication of how far away from home they feel to be, in another symptom of the devastating events that have happened to them in the battlefield. 


\section{Men marched asleep.}

Owen once again emphasizes how exhausted the soldiers were - this time, by means of the contradiction between their militaristic, disciplined marching, and the fact that it was carried out as if the men were sleeping. The reader may make the connection between that image and that of someone who seems to be sleepwalking because they are so tired that they are no longer able to be aware of what surrounds them.

\section{Many had lost their boots but limped on, blood-shod.}

Even those with no footgear kept going. Their "limping on, blood-shod" exposes their condition. Their own coagulated, hardened blood was what covered their feet, instead of the boots they had lost.

The fact that many were in that situation might also be a way for the author to emphasize how dramatic the situation was, as losing their boots and having to go on limping was not something that happened to only a few of the soldiers. The reader can here understand that such an extreme predicament was common.

\section{All went lame; all blind;}

The continuum seems to be even clearer here, as many gives way to all. Going lame and blind is something that eventually affected every single soldier. The description of the suffering of the soldiers appears to be in a crescendo, as not one of them could now walk - or even see properly. The reader could have an even stronger sense of the hopeless state of the soldiers. 


\section{Drunk with fatigue;}

The soldiers were apparently so exhausted that they thought and moved with the same difficulty of drunken people, which is another image that emphasizes to the reader the fact that the men had reached the limits of their resilience.

\section{deaf even to the hoots}

\section{Of disappointed shells that dropped behind.}

The soldiers seem to have been so tired that they were unable to even register the sound of the bombs that fell behind them. Calling the sound a hoot means that it was loud and deep as that produced by an owl.

Saying that the bombs - shells - were disappointed is an instance of animacy. It could mean that the German artillery had failed to reach the allied soldiers and had, therefore, failed to achieve its objective.

\section{GAS! Gas! Quick, boys!}

At the beginning of the second section of the poem, the exclamations and the use of capital letters in the first word appear to indicate a dramatic shift in the pace of the poem, and look like exclamations that were directed by the soldiers themselves - perhaps by the author, perhaps by one or more of his companions - to each other. The reader may perceive a sense of urgency whose justification is made clear from the start.

\section{An ecstasy of fumbling,}

As the soldiers reach for their gas masks, their efforts seem to be awkward and as feverish as when one is in a state of extreme happiness and delight. The choice of a noun that is normally associated with a positive sensation could momentarily reverse the expectations of the reader and yet make it easier for them to visualize that moment of intense activity. 


\section{Fitting the clumsy helmets just in time;}

The adjective clumsy seems to be another instance of animacy. The masks themselves could not have been clumsy, but the soldiers, in their desperation to put them on, apparently were.

The fact that the masks were put on just in time could remind the reader of the urgency of the moment, and of how easy it would have been for the soldiers to miss the brief window of opportunity that they had to protect themselves.

\section{But someone still was yelling out and stumbling}

\section{And floundering like a man in fire or lime.}

So difficult was the situation that one of the soldiers failed to put his mask on in time. His yelling out and stumbling seems to reflect his desperation, as both verbs refer to actions that are characteristic of a state of terror and lack of control.

He was floundering, or moving with a lot of difficulty and effort, as if he was burning, which is the effect of being "in fire or lime". The reader can now begin to see the ways in which the victim of a gas attack suffers from it.

\section{Dim, through the misty panes and thick green light}

The author appears to present here his own perspective, as he looked at the soldier who failed to put on his gas mask. Through the green panes of the gas mask, everything seems green. The adjectives dim, misty and thick all seem to lead the reader to imagine how little clarity there was, how fuzzy the image of the dying soldier looked to the narrator.

\section{As under a green sea, I saw him drowning.}

Even though the men were on dry land, the destruction of his lungs caused by the gas would have prevented the soldier from breathing. The "sea" of gas, green because it was seen through the panes of the mask, was where the narrator saw his comrade die. The reader is 
presented with the statement "I saw" and can become aware of the fact that the witnessing of a death is at the center of the story.

\section{In all my dreams, before my helpless sight,}

The narrator now tells the reader that the memory of the incident is always with him - in "all his dreams", which is quite significant, as the totality of his dreams appear now to be nightmares about that day.

In those nightmares, he relives the scene helpless, unable to help the dying soldier, as he probably felt on the day of the attack. The reader seems to be presented here with the notion of the narrator's impotence in face of the tragedy.

\section{He plunges at me, guttering, choking, drowning.}

In the nightmare, the desperate, dying soldier thrusts himself onto the narrator, which could be the ultimate expression of his desperation, seeking for help. Yet the narrator is helpless himself.

The three verbs that follow seem to establish another clear continuum that allows the reader to imagine the moment of the soldier's death. Guttering means to flow in rivulets, or the melting away of a candle - in either case, an image that is more delicate than dramatic. Choking is more serious, as the amount of fluid becomes too much for the man to handle. Drowning leaves no escape, for, because the soldier's lungs have now collapsed, it is as if he was submerged in the "green sea". The repetition of this last word, which also closed the previous section, only two verses before, could enhance the force of the idea, and make it more likely to stay on the mind of the reader. 


\section{If in some smothering dreams you too could pace \\ Behind the wagon that we flung him in,}

The final stanza of the poem begins with the poet addressing the reader directly for the first time, with the pronoun you. He seems to be ready to reach his conclusion. In fact, the entire stanza can be read as a statement in the second conditional.

The hypothetical begins with the imaginary situation of the reader finding themselves in the same situation of the narrator, walking behind the wagon that carried the dying soldier. That imaginary situation would take place "in some smothering dream", which seems to present the reader with the condition of sharing the nightmares that the narrator has. The nightmare itself would be smothering, suffocating, in a possible parallel with the suffocation of the gas victim himself.

The soldier was flung into the wagon, which means it was not placed there with care, but in a sudden and forceful way. That could indicate to the reader that the situation did not allow for the victim to be treated with gentleness. In the middle of a war zone, moving a soldier who is inevitably going to die could not be a solemn procedure.

\section{And watch the white eyes writhing in his face,}

Besides walking behind the wagon, two more actions are described by the author as part of the hypothetical dream that the reader would share. The first one is to watch the man's eyes twisting in pain. The reader can here imagine themselves looking at the man as he dies, and taking in the suffering.

\section{His hanging face, like a devil's sick of sin;}

This verse seems to contain a description of how deformed the soldier's face was made by the effects of the gas. It was hanging, as if no longer properly attached to muscles and bone. The face is compared to that of a devil that is "sick of $\sin$ ". That could represent the highest level of disgust, as a devil who is sick of sin would be one who has experienced too much depravity, to the point of being repelled by it. As a devil would be a creature of sin 
themselves, such extreme depravity would have to be beyond any and every limit. Owen could be saying here that the evil of war is at such a level.

The reader can here imagine that the face of the dying soldier is therefore an expression of the most intense suffering.

\section{If you could hear, at every jolt, the blood}

\section{Come gargling from the froth-corrupted lungs,}

The second action that the author seems to propose the reader to share with him in the nightmare is to hear the gargling blood of the soldier at every jolt of the wagon. Every jolt indicates that the sound comes at every single irregularity of a terrain that one might imagine very irregular, which is that of the area of the trenches. The sound would then be very frequent.

That sound is that of the blood that comes from the victim's lungs. That is probably a terrible sound, as the knowledge that it comes from the lungs would make it the sound of dying itself.

Saying that the lungs have been corrupted by the bubbles formed in the liquid seems to contain negative appraisal, making it clear to the reader that the lungs are being destroyed.

\section{Obscene as cancer,}

The dying man's blood coming from his lungs is the object of what could be seen as a simile that is filled with negative appraisal. It is described as being as obscene as cancer. Even though so much more is understood about cancer nowadays than in 1918 , it could be argued that the word still carries strong negative connotations, and is still used as a metaphor for something - or someone - evil that contaminates the area around it. It is conceivable that such and interpretation was even more common, one hundred years ago, and that Owen's contemporaries saw in that line a characterization that was even stronger than the one we see today. 


\section{bitter as the cud}

\section{Of vile, incurable sores on innocent tongues,}

In one last simile, also referring to the blood gargling from the lungs, Owen calls is bitter, which means he now seems to be talking about the taste of that blood in the soldier's mouth. That appears to be reinforced by the comparison of the blood to cud, which would also present the reader with another undesirable taste, that of regurgitated food.

That cud is made of sores which are both vile - an adjective with a high degree of negative appraisal - and incurable - as incurable were the very effect of the gas. The fact that those sores are on innocent tongues could be a reference the youth of the soldiers who were fighting in that war. Wilfred Owen, a young man himself who would not live to see the end of the war, appears to wish to leave his readers with the image of the loss of innocence World War I came to represent in so many ways to future generations. Just before the conclusion of the poem, the reader might be thinking of the injustice of such tragic events happening to young men.

\section{My friend,}

There does not seem to be much room for controversy regarding who that friend was. The poem was originally addressed to Jessie Pope, and later to 'a certain Poetess'. Like Rupert Brooke, Pope was famous for writing patriotic verses and some of her 'recruitment poems' could be quite aggressive. Although the dedication was later removed so that the poem could reach a larger audience, Owen's readers at the time of the War could have understood the reference.

\section{you would not tell with such high zest}

\section{To children ardent for some desperate glory,}

The nucleus of the clause in the second conditional sentence that expresses the consequence seems to be here, with the main verb tell at its center. If Jessie Pope - or anyone else - could experience all that the poet describes in the previous verses, there is something they would 
not tell children. In typical second conditional form, the modal introduces the result that is predicted by the author of the hypothetical that had been proposed by him in the 'if' clauses. He appears to be certain that what he says here would be the result. The reader is to be left with that certainty.

That which would not be told to children were the hypothetical true would have to be what is told in reality, and told with high zest. Owen's readers might see here that there is something that is being told with a great sense of enjoyment and enthusiasm. The adjective such to qualify the high zest appears to mean that the author believes that there would be less zest from the addressee of the poem.

Those to which something is being told are characterized as children, which could be literal, or, what seems to be more likely, referring to young men who, in their innocence, are willing to go fight in the War. The fact that they are ardent for glory which is desperate seems to be a way for the author to emphasize not once, but twice how eager those young men are. The reader might see here a sense of great urgency from the children in achieving glory.

The glory itself might be what the young men who were unaware of the reality of combat, and thus susceptible to the influence of recruitment verses, equaled to being soldiers in the War.

\section{The old Lie: Dulce et decorum est}

Pro patria mori.

The Latin verse is a line from the Roman lyrical poet Horace's Odes, and it translates as 'it is sweet and proper to die for one's country'. Often quoted to celebrate the sacrifice of those who have died in battle, the phrase is the motto of military organizations in several countries. Owen calls it the lie that is being told to young men during the War. By doing that, he appears to be making his position clear to the reader: dying for one's country is neither sweet nor proper, as authors like Pope (and Brooke) might say, but rather quite terrible.

Owen does not say the phrase 'is a lie', but nominalizes and finishes with the noun Lie, thus apparently leaving his readers no alternative but to accept that the Latin phrase is indeed a lie.

Finally, the apparently unjustified capitalization of the initial $L$ in Lie seems to indicate that the author wishes to present the phrase as especially important. The capitalization could be a way of highlighting its importance to the reader. 
Precisely on the eve of Rupert Brooke's death, the Germans carried out, at Langemark, Belgium, the first significant use of gas in war, which is what Wilfred Owen vividly describes in his poem. Owen, who, before becoming a soldier, even wrote a pro-war poem, was profoundly affected by what he experienced. Although he fully believed in his responsibilities as a soldier, in the end, he felt, very much like Sassoon, that it was also his duty to alert the people about the horrible reality of war (ROBERTS, 1996). He wrote that "all a poet can do today is warn. That is why the true Poets must be truthful".

Wilfred Owen expresses with unparalleled accuracy the true horrors of trench warfare. The semantic effect he achieves is that of letting his readers get as close as possible to the suffering of the soldiers, in such a way that neither his generation nor any of the ones that have come since can claim to ignore the fact that dying for one's country may be necessary, but it is not 'sweet and proper'.

Owen enlisted in October of 1915. Suffering from shell-shock after a series of traumas that included gas attacks, he was sent to military hospitals in France, then Hampshire, and finally Edinburgh, where he met fellow English poet Siegfried Sassoon, whom he greatly admired and who influenced him to develop his poetry. Owen was able to merge his romantic style with Sassoon's gritty realism, in a poetic synthesis that resulted in a body of work that is both potent and sympathetic. He was killed by German fire on November $4^{\text {th }}, 1918$, exactly one week before the armistice. 


\section{Analysis of the Exploratory Practice Activities}

\subsection{First Activity}

After having the poems read to her, teacher Sandra Saito shared the images which came to mind. What follows are the two scenarios she pictured for each poem.

The Soldier

The poem is a letter, or an entry in a journal that he's leaving for his son.

or

He's 18 years old, and very excited about going to war, about standing for England, because he adores England. He looks at his mother. He looks at his father, who's too old to go to war. The man is going to stand for his family and for England. He's packing his bag. His clothes, everything he's taking. He goes into the living room with the bag on his shoulder. He looks at his family. His mother hugs him. He holds his mother by her shoulders and tells her everything that is in the poem. He wants to make his parents proud, because he's going to fight with all he has. If he dies, he's going to die with honor, for he'll be dying for his country. Even if nobody ever finds his body, his parents will always know. 
Dulce et Decorum Est

He is camping with his friends and remembering the time of the War. He speaks in a very dramatic manner. His hair moves from side to side when he speaks.

or

He is at a pub, he gets drunk. He has a glass of whisky in his hand, and he's telling his tale to everyone who is there. It's a small pub. He's telling his war stories. Sometimes he raises his glass. Sometimes he screams. Sometimes he slams his glass on the counter. When he reaches the end, he raises his glass once more.

On November $22^{\text {nd }}, 2015$, I discussed the poems again with teacher Saito. I told her more about the circumstances of Rupert Brooke's and Wilfred Owen's writings and respective deaths, read the poems to her one more time and told her about my interpretation of both pieces. This is what she had to say:

- Knowing that Brooke died and indeed became a corner of a foreign field that is for ever England, it is somewhat anticlimactic to learn that he died as a result of a mosquito bite rather than in combat. He was, however, a piece of England, which is a country that deserves to be celebrated - a country of kings, queens and revolutions, full of natural and historical richness. Brooke was not just anyone, but someone who died to protect that land.

- One wonders what Owen's real reasons to enlist were, but when he got there he was fighting to save himself and his comrades - not England. His irony is justified, for the ones who sent him to fight are sitting comfortably in their offices behind their desks, yet they are ones who are going to be celebrated afterwards. We only remember Owen because he could write. When you're over there, you're all alone. It's just you 
and the enemy who is trying to kill you. Your boots will not necessarily fit your feet, your gas mask will not necessarily fit your head, your gun will not necessarily work as it should. The men behind their desks do not care.

Teacher Saito's impressions relate to my linguistic analysis in her perception of the idyllic scenario described by Rupert Brooke and of the harsh reality in Wilfred Owen's tale. The images which occurred to her can be seen as natural extensions of the affect, judgment and appreciation I identified in the poems. There is room for negotiation of our respective points of view in this search for valid knowledge (GUBA; LINCOLN, 2000, p. 177).

\subsection{Second Activity}

In the following reproduction of the cloze activity, the words suggested by the students are after each gap. In a couple of cases, they could think of nothing; in a few others, their ideas were excellent. In spite of the difficulty they had, they clearly enjoyed being shown what the actual missing words were.

The Soldier

If I should die, think only this of me:

That there's some corner of a foreign field

That is for ever (alone/abandoned). There shall be

In that rich earth a (single/small) dust concealed;

A dust whom England bore, shaped, made aware,

Gave, once, her (ways/chance/heart/name) to love, her ways to roam;

A body of England's, breathing English air,

Washed by the (tears/light/water/rain), blest by suns of home. 
And think, this heart, all evil shed away,

A pulse in the eternal mind, no less

Gives somewhere back the (love/soldiers) by England given;

Her sights and sounds; dreams (rise/light/sweet/bright) as her day;

And laughter, learnt of friends; and gentleness,

In (earth/place) at peace, under an English heaven.

Dulce Et Decorum Est

Wilfred Owen

Bent double, like old (land) under sacks,

Knock-kneed, coughing like hags, we cursed through sludge,

Till on the haunting flares we turned our backs

And towards our distant (way/place/land/fate) began to trudge.

Men marched asleep. Many had lost their boots

But limped on, blood-shod. All went lame; all blind;

Drunk with (pain/blood/hope); deaf even to the hoots

Of disappointed shells that dropped behind.

GAS! Gas! Quick, boys!-- An ecstasy of fumbling,

Fitting the clumsy helmets just in time;

But someone still was (no ideas) out and stumbling

And floundering like a man in fire or lime.--

Dim, through the misty panes and thick green light

As under a green sea, I saw him (fight/cry/die).

In all my dreams, before my helpless sight, 
He plunges at me, guttering, choking, drowning.

If in some smothering dreams you too could pace

Behind the wagon that we flung him in,

And watch the white eyes writhing in his face,

His hanging face, like a devil's sick of sin;

If you could (breathe/see), at every jolt, the blood

Come gargling from the froth-corrupted lungs,

Obscene as (no ideas), bitter as the cud

Of vile, incurable sores on innocent tongues,--

My friend, you would not tell with such high zest

To (burn/fight) ardent for some desperate glory,

The old Lie: Dulce et decorum est

Pro patria mori.

On November $16^{\text {th }}, 2015$, I went back to those students and finally told them that that exercise had been a part of this paper, and that their responses would be included, which they were surprised and happy to hear. As we had a brief conversation about the two poems, the students' reactions can be summarized in the following manner:

- They now believed to understand the main point of each poem;

- They were greatly impressed by what eventually happened to Brooke and to Owen;

- They liked Dulce Et Decorum Est better, because it "said something about the reality of war".

Several of the words that the students proposed in the activity are remarkably close, respectively, to the positive and negative, stronger and weaker choices made by Brooke and Owen, as interpreted in my analysis. Such proximity, of course, proves nothing, but adds to the dialogical aspect of this research. 


\section{Conclusions}

The analyses of the two poems revealed the various linguistics mechanisms used by Rupert Brooke and Wilfred Owen in order to realize their desired semantic effects, creating vivid, if opposed, images of what going to war meant to men who lived one century ago. Throughout he analysis, it was possible to notice that the fact that the two men were writing within the same context of culture - World War I England - but, as mentioned in the Introduction, rather distinct contexts of situation, seems to have led them to pointedly different sets of linguistic choices. The two EP activities provided complementary perspectives, as the ideas that occurred to teacher Saito and to the students who participated showed that The Soldier and Dulce Et Decorum Est still have something to say, at this time when sacrifice oneself for one's country has meant enduring horrors which could not be imagined until rather recently.

A few days after what was supposed to be our last conversation about the poems, teacher Saito asked which of the two poems spoke to me the most. After some moments of reflection, I answered that, to me, Brooke's vision was - is - a source of inspiration, which is an essential part of human life. What Owen had to say, however, was about opening our eyes to the realities of war. That can lead to an improved sense of perspective. In the words of Carl Sagan, "think of the rivers of blood spilled by all those generals and emperors so that in glory and triumph they could become the momentary masters of a fraction of a dot" (SAGAN, 1994). In this so often chaotic world, that seems to be even more necessary.

Between the second and the third semesters of the post-graduation course of which the present work is a product, I had the opportunity to visit the memorial to World War I poets which is located in the Poets' Corner inside Westminster Abbey, in London. The memorial is a slate stone slab with the names of the poets inscribed on it, and a quote by one of them - none other than Wilfred Owen. His is the final word. The quote reads:

My subject is War, and the pity of War. The Poetry is in the pity. 


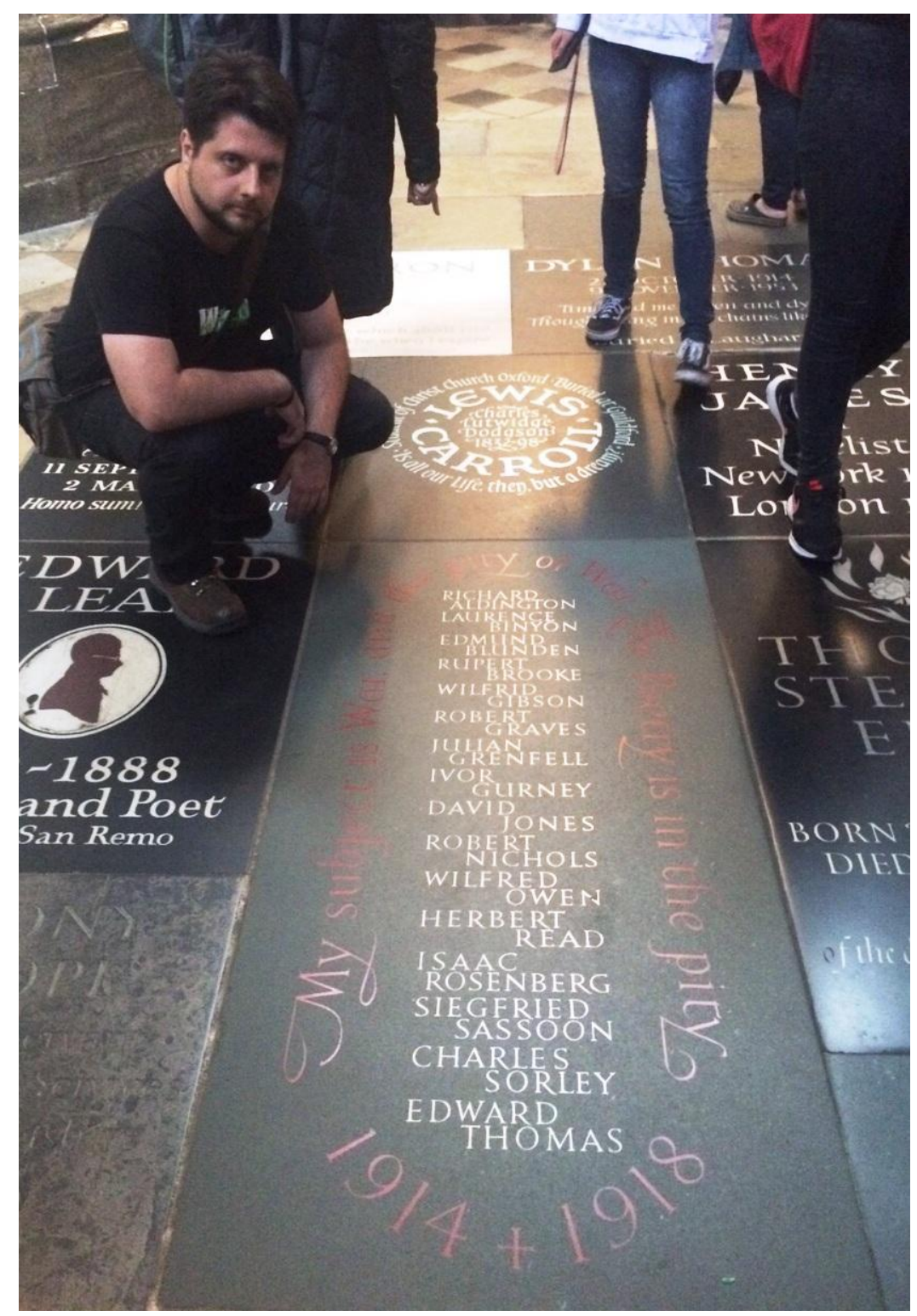

Figure 5: World War I Poets Memorial 


\section{References}

ABRAHAM LINCOLN ONLINE. The Gettysburg Address. Available at <http://www. abrahamlincolnonline.org/lincoln/speeches/gettysburg.htm>. Access on: October 18, 2015.

ALLWRIGHT, D. Exploratory practice: an 'appropriate methodology' for language teacher development? 2000. Available at <http://www.letras.puc-rio.br/unidades\&nucleos/ epcentre/readings/IALS\%20PAPER\%20DRAFT.htm> Access on: February 26, 2016.

Three major processes of teacher development and the appropriate design criteria for developing and using them. In: JOHNSTON, B. \& IRUJO, S. (Eds.). Research and practice in language teacher education: voices from the field. Minneapolis: CARLA Working Paper, No. 19, 2001. Pp. 115-133.

BUTT, David et al. Using functional grammar - An explorer's guide. National Centre for English Language Teaching and Research, Macquarie University, 2000.

EGGINS, Susan. An introduction to systemic functional linguistics. New York: Continuum, 2004.

EGREMONT, Max. Some desperate glory: the First World War the poets knew. Picador, 2014.

GUBA, E.G; LINCOLN, Y.S. Competing paradigms in qualitative research. In: DENZIN, N.K.; LINCOLN, Y.S. Handbook of qualitative research. Thousand Oaks: Sage, 1994. Chapter 6, pp. 105-177.

GUBA, E.G; LINCOLN, Y.S. Paradigmatic controversies, contradictions, and emerging confluences. In: DENZIN, N.K.; LINCOLN, Y.S. Handbook of qualitative research. $2^{\text {nd }} \mathrm{Ed}$. Thousand Oaks: Sage, 2000. Chapter 6, pp. 163-188.

HALLIDAY, M.A.K.; HASAN, R. Language, context, and text: aspects of language in a socialsemiotic perspective. Oxford: Oxford University Press, 1989.

MARTIN, James R. Design and practice: enacting functional linguistics. Annual Review of Applied Linguistics, 20, 116-126. Cambridge: Cambridge University Press, 2000.

- Beyond exchange: appraisal systems in English. In: HUNSTON, S.; THOMPSON, G. (Eds). Evaluation in Text. Oxford: Oxford University Press, 2000.

MARTIN, J.R.; WHITE, P.R.R. The language of evaluation: appraisal in English. London: Palgrave, 2005.

MYCROFTLECTURES (a). Rupert Brooke - The Soldier - Full lecture and analysis by Dr. Andrew Barker. Available at: <https://www.youtube.com/watch?v=DB6nUtRSPxg\&index=2>. Access on: June 22, 2015. 
MYCROFTLECTURES (b). Wilfred Owen - Dulce Et Decorum Est - Full lecture and analysis by Dr. Andrew Barker. Available at: <https://www.youtube.com/watch?v=DB6nUtRSPxg\&index $=2>$. Access on: June 22, 2015.

ROBERTS, David. (Ed.). Minds at war - poetry and experience of the First World War. Hurst: Saxon Books, 1996.

SAFIRE, William. Essay; Disaster Never Came. The New York Times, New York City, July 12, 1999. Opinion. Available at: <http://www.nytimes.com/1999/07/12/opinion/essay-disasternever-came.html> Access on: November 22, 2015.

SAGAN, Carl. Pale Blue Dot: A Vision of the Human Future in Space (1st ed.). New York: Random House, 1994. 